\title{
MI-2 HELICOPTERS OPERATING AT SEA
}

\section{Miłosz Rusiecki}

\begin{abstract}
The article describes participation of Mi-2 helicopters in both military and civilian operations at sea. Although the multipurpose $\mathrm{Mi}-2$ rotorcraft were not designed to operate in the harsh environment over the sea, they became - in the second half of the 1960s and in the 1970s - a standard type performing a wide array of tasks at sea. Modern turboshaft engines, a favorable weight-to-power ratio and a dual engine configuration were all factors enabling safe flight over the sea, at considerable distances from land. The specialized Mi-2RM variant designed by WSK PZL Świdnik provided the Naval Aviation with an opportunity to establish, in the 1st half of the 1970s, a unique marine air rescue system. The last Mi-2RM used for rescue missions was decommissioned as late as in 2010, although at that stage it was only used for aircrew training purposes. The Navy was also using the Mi-2Ch variant tasked with creating smokescreens to conceal vessels and port facilities. General purpose variants of the helicopter were used to transport people and goods. They also performed well during patrolling missions and while identifying various types of contamination.

As far as civilian use of the helicopters is concerned, Mi-2 versions equipped with special purpose on-board systems supported scientists in the exploration of the Antarctica at two stations of the Polish Academy of Science. The Maritime Authority in Gdynia was also using its own Mi-2 helicopter for over 30 years - until 2015 - for patrolling the Gdańsk and Puck Bays and waters around the Hel Peninsula. The missions were focusing primarily on detecting potential contamination of the coastal areas.

In the former Soviet Union, civilian Mi-2 variants were (and still are) standard equipment of deep sea icebreakers operating in the Arctic and around the North Pole. The machines are mainly used for safety purposes, as well as for transporting scientists and groups of extreme tourists. Approximately a dozen Mi-2 purchased from Russia in the mid-1990s, in turn, were used by the Aviation Force of the Mexican Navy. Unfortunately, no further details regarding their use are available.
\end{abstract}

Keywords: helicopters, sea operations, Mi-2 versions, military and civilian use of the Mi-2 helicopter.

\section{INTRODUCTION}

The multipurpose, turboshaft-powered Mi-2 helicopters were not designed for operating in the harsh sea environment. However, as they were, in the 1960s and 1970s, the most technologically advanced machines of their type, they were also relied upon to perform missions that required the highest level of operational readiness of equipment, and the highest level of aircrew training. 


\section{MI-2RM - SPECIALIZED OFFSHORE RESCUE HELICOPTER}

Almost immediately after launching lot production, the Świdnik plant commenced work on designing a specialized rescue version coded Mi-2RM, with its prototype first flown in the 1st half of 1969.
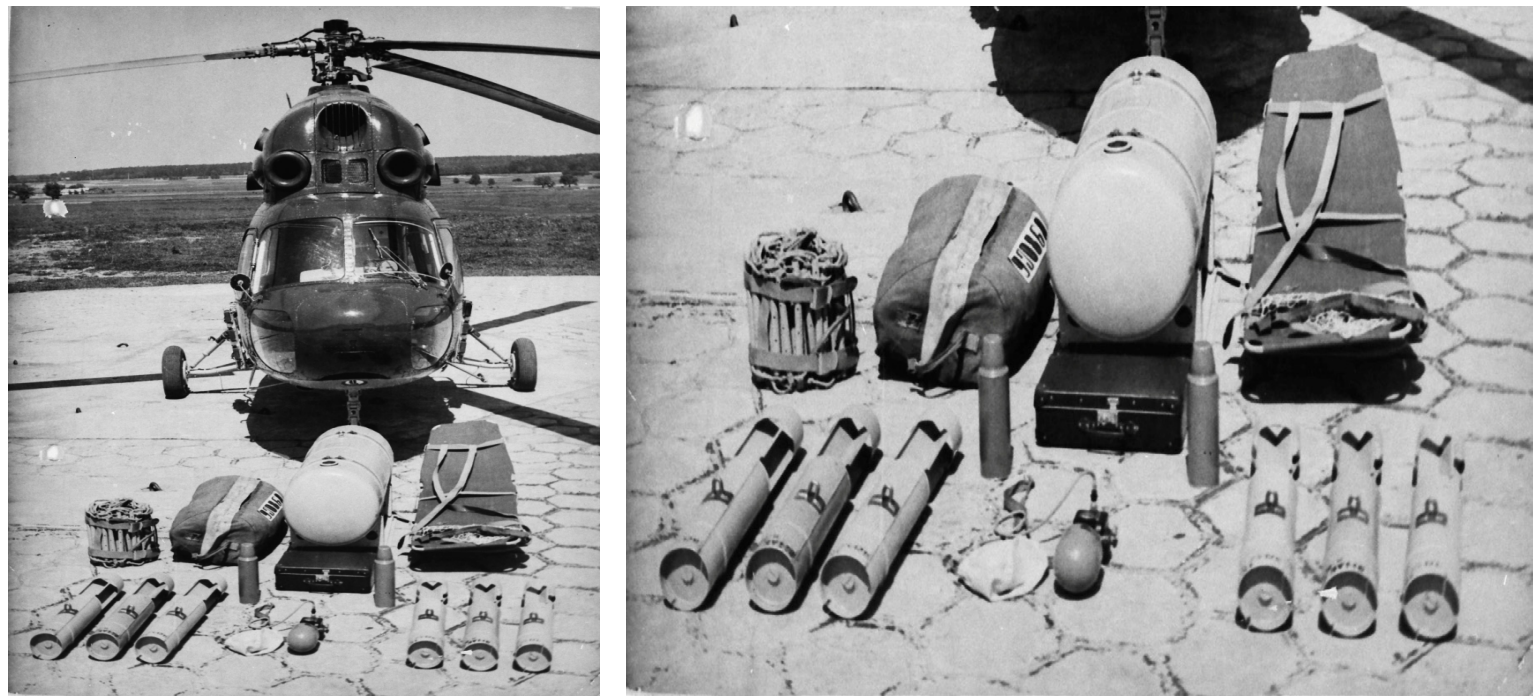

Fig. 1. The prototype Mi-2RM and its equipment. From left to right: rope ladder, rescue raft, additional (cabin-mounted) fuel tank, illumination and smoke bombs OMAB-25-12D and OMAB-25-8N, etc. Images: ITWL archives, via Jerzy Gruszczyński

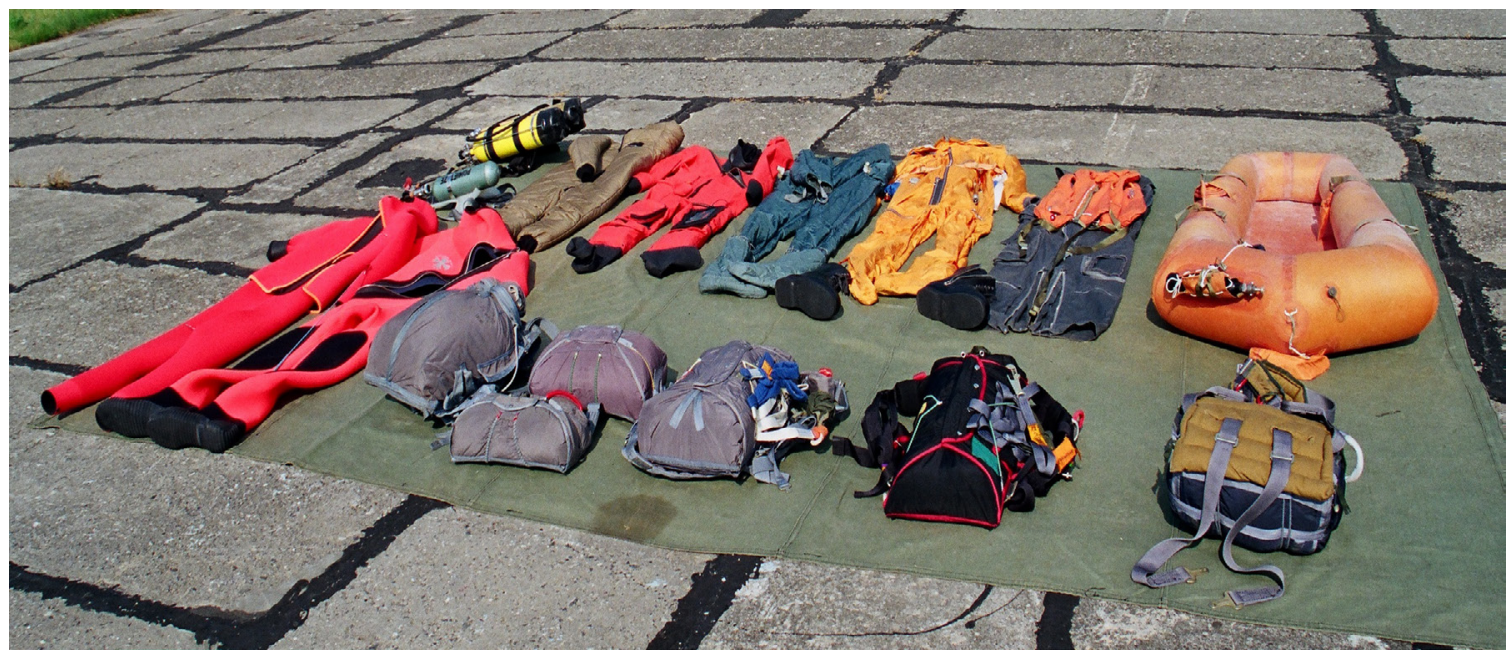

Fig. 2. Similar equipment 30 years later. Personal protection and rescue gear of the crew is visible - thermal overalls, rescue vests, oxygen cylinders and parachutes. Image: Miłosz Rusiecki

The fuel system of this particular version of the rotorcraft was modified, with the left fuselage-mounted tank replaced by three signaling bombs of type OMAB-25-12D (used in daytime and generating thick, colored smoke) or OMAB-25-8N (used at night, serving as illuminating flares). The 
helicopter could still be equipped with the left fuselage-mounted fuel tank. The cabin was equipped with a stretcher, a first aid kit and a rescue raft. The cargo hook mounted under the fuselage was adapted to towing such rafts behind the aircraft. An additional searchlight operated by the co-pilot was mounted on the starboard side main landing gear strut. The ARK-U2 radio direction finder was installed in the cockpit. It scanned the international rescue frequencies to identify any radios, including portable ones, sending emergency calls / signals. From the 1990s, some units were also equipped with an additional GPS receiver. The communications system was modified as well, and was supplemented by an analog, integrated SPDR-2 unit.
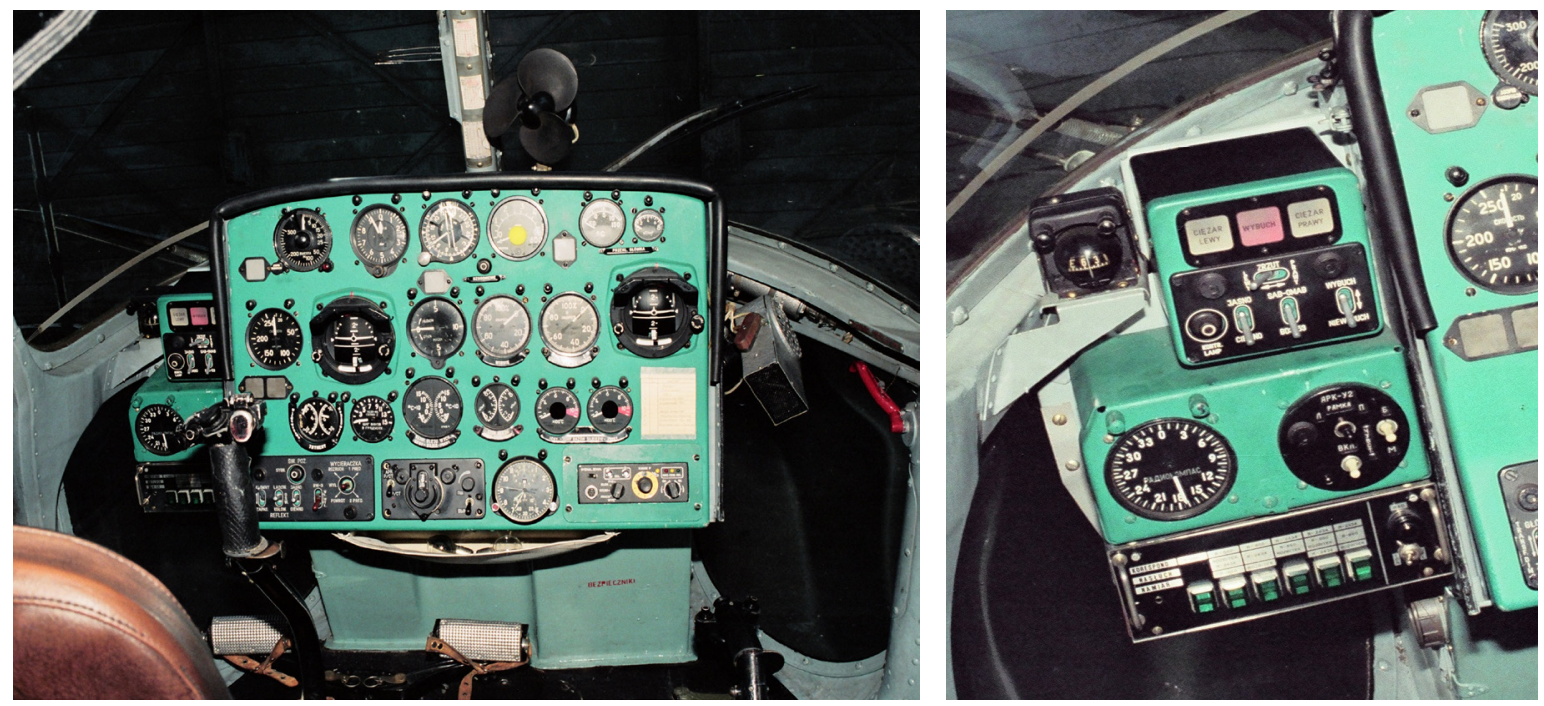

Fig. 3. Mi-2RM control panel with a close-up with of the ARK-U2 radio direction finder, used for scanning international rescue frequencies to identify any radios, sending emergency calls. Images: Miłosz Rusiecki
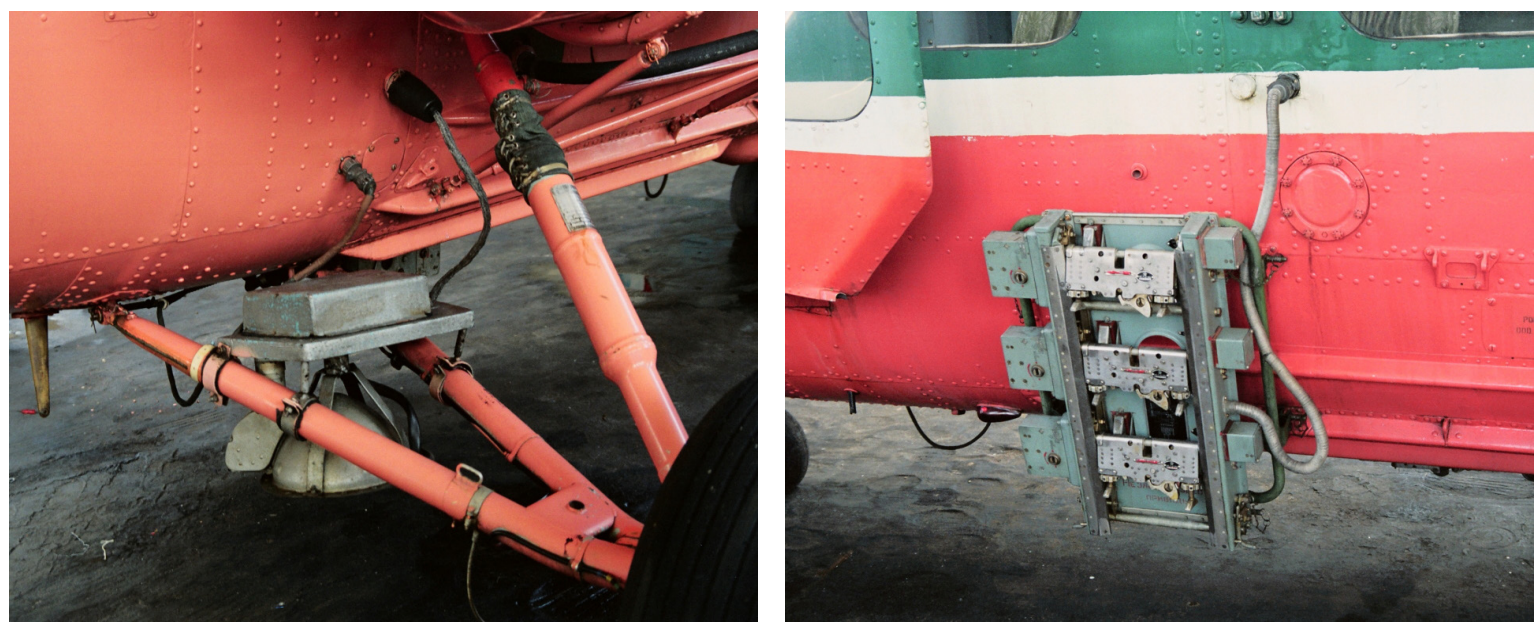

Fig. 4. Additional searchlights on the starboard side main landing gear strut, along with attachments for signaling bombs. Images: Miłosz Rusiecki 
Equipping the helicopter with a rescue hoist has turned out to be rather problematic. Sea rescue procedures assumed that a specialist - a rescuer - was to be lowered to the person in danger, with both of them winched on board together. Meanwhile, the only standard winch manufactured in the USSR (ŁPG-4) had the maximum capacity of $120 \mathrm{~kg}$ (1 person). The decision was made to spend hard-to-come-by foreign currency and procure Finnish, pneumatic winches capable of lifting two people simultaneously. The winches were powered by one, thick pneumatic line mounted on the port side of the fuselage. However, problems with controlling the winch in a precise manner were encountered, which has rendered it useless for rescue operations. The problem was finally solved by purchasing hydraulic French winches. The hook mounted under the helicopter, with a lock enabling towing rafts, was still controlled pneumatically. The winches were operated, without any significant problems, until the end of the helicopters' service life. Hydraulic lines connecting the pump mounted inside the cabin, next to the door, and the winch were routed outside the fuselage, over the window line. The cover of the entire mechanism was available in two versions - streamlined and "box-like".
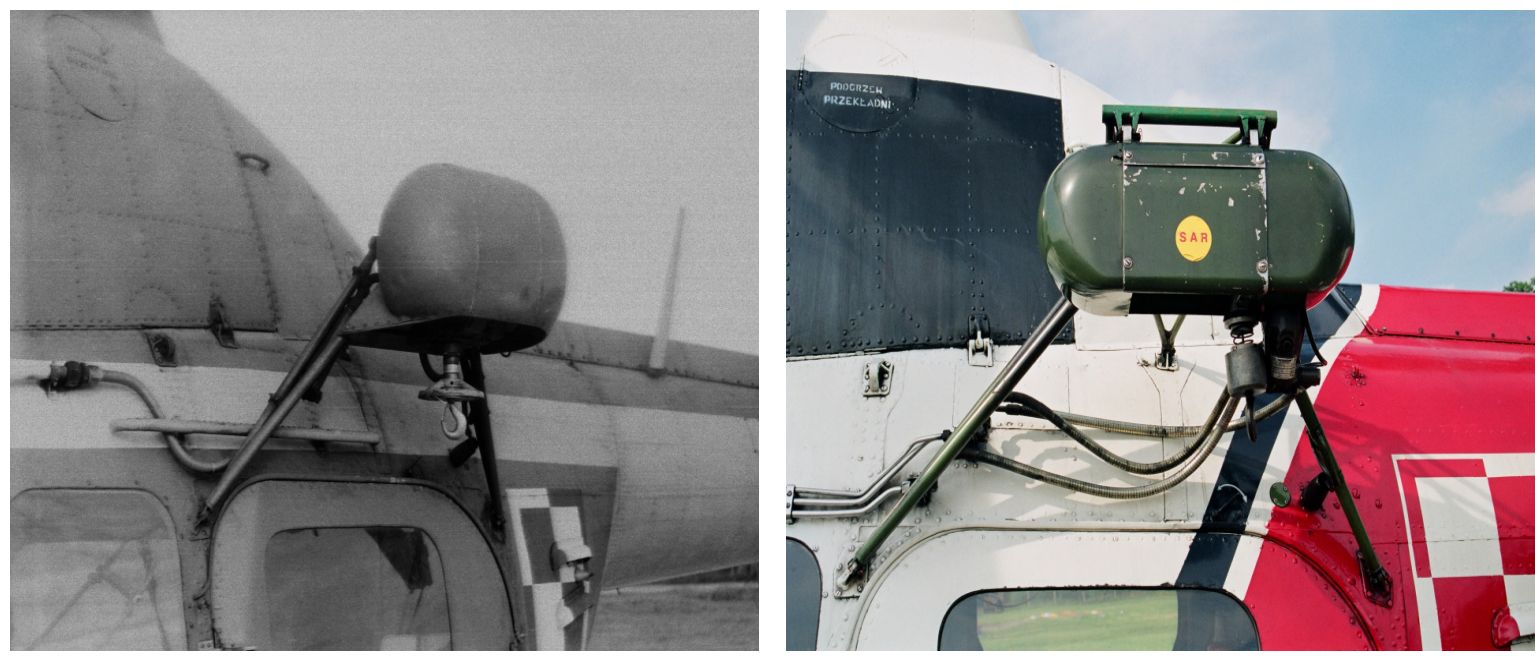

Fig. 5. Left - pneumatic winch, right - hydraulic winch. Images: Miłosz Rusiecki

Other pieces of rescue equipment have been tested as well, but never became part of the standard configuration of the aircraft. The military performed experimental drops of SAB-100 illumination flares, lighting the areas in which sea rescue efforts were conducted at night. The attachments for those cartridges replaced the multi-racks for signaling bombs mounted on the port side of the fuselage.

In 1978 and 1979 the Institute of Aviation tested a new Polish radio semi-compass, designed by a team headed by Krzysztof Kunachowicz. It was intended to locate those in distress and equipped with personal emergency beacons operating at the frequency of $121.5 \mathrm{MHz}$. The peculiar dipole antennas of the receiver mounted on the helicopter's nose quickly earned in the nickname of a "Mi-2 with a moustache". The tests were performed by pilots Stanisław Wielgus and Ryszard Witkowski, with the participation of the designer of the direction finder. The test program confirmed that the system was operating efficiently and effectively. However, alleged reservations voiced by the Soviet side have prevented it from entering lot production. 




Fig. 6. Mi-2 "with a moustache", equipped with the experimental emergency signal receiver / direction finder, designed by Krzysztof Kunachowicz, Eng. Image: Institute of Aviation via Ryszard Witkowski

A little earlier, in the first half of the 1970s, a team was appointed in Świdnik, headed by Władysław Burdan, and commenced work on inflatable emergency floats for the Mi-2. The design reached the prototype stage. In the fall of 1974, the newly constructed Zemborzyce Reservoir near Lublin served as testing grounds on which water landings and take-offs of a helicopter with the serial number of 543042 123, equipped with the device, were conducted. It was piloted by Stanisław Gajewski. The tests were successful. However, due to technical problems and difficulties with the material used, the program was abandoned.

Only the last Mi-2Plus units produced to the order of the Indonesian Police, were equipped with six-point floats.


Fig. 7. Left - Mi-2 helicopter with floats designed by Władysław Burdan, Eng., during tests on Zemborzycki Reservoir, 1974. Right - Mi-2Plus for the Indonesian Police, with six emergency floats, 2006.

Images: Karol Budniak's file. 
Interestingly, Russian language publications dealing with the $\mathrm{Mi}-2$ present its side cross-section with huge, parallel floats. The drawing is labeled as Mi-2M (as in "Morskoy”, „Marine”). However, no information is provided on whether such a variant has ever been tested in practice. No other images are presented as well. The Mi-2 serial number 525150047 (SP-SBO), in turn, was equipped - while serving temporarily in Canada in 1981 - with emergency floats designed by one of Western suppliers.

\section{MI-2 SERVING IN THE NAVY}

The Naval Aviation commenced using helicopters in 1960. The first types used were the piston-powered SM-1 which were joined, in December 1962, by the SM-2 variant. They were used primarily for communication, patrol and contamination identification missions. The SM-2s, equipped with simple winches, were used as rescue helicopters as well.
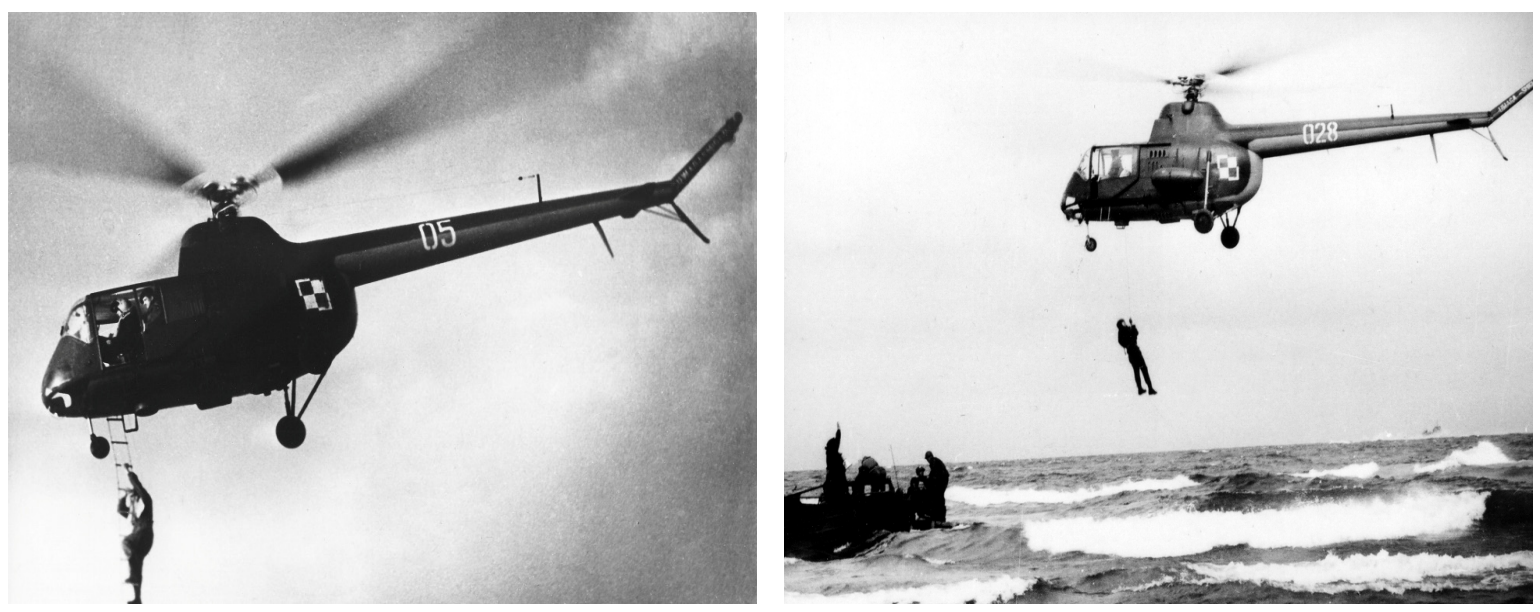

Fig. 8. Left - The SM-2 with a rope ladder, image - Karol Budniak's collection, Right - The SM-2, even equipped with a winch, could only conduct rescue missions in the coastal zone, image - WAF.

However, the single engine producing insignificant amounts of power, and the peculiar design features of the helicopter severely limited its operational capacity. Therefore, the first two Mi-2s delivered in March 1968, although in the passenger and transport variant, heralded the arrival of a new era. It was only the prototype Mi-2RM, serial number 0815, delivered in August 1969, however, that fully showcased the potential of the new helicopter. After a trial period, the variant was finally approved for series production. Between December 1971 and July 1973 the Navy took delivery of 16 series-produced Mi-2RMs that were assigned to the squadrons stationed in Gdynia (originally 5 units) and in Darlowo (11 units). The two squadrons were the foundation stone of an air sea rescue network - a pioneering undertaking of this type on the southern coast of the Baltic Sea. 


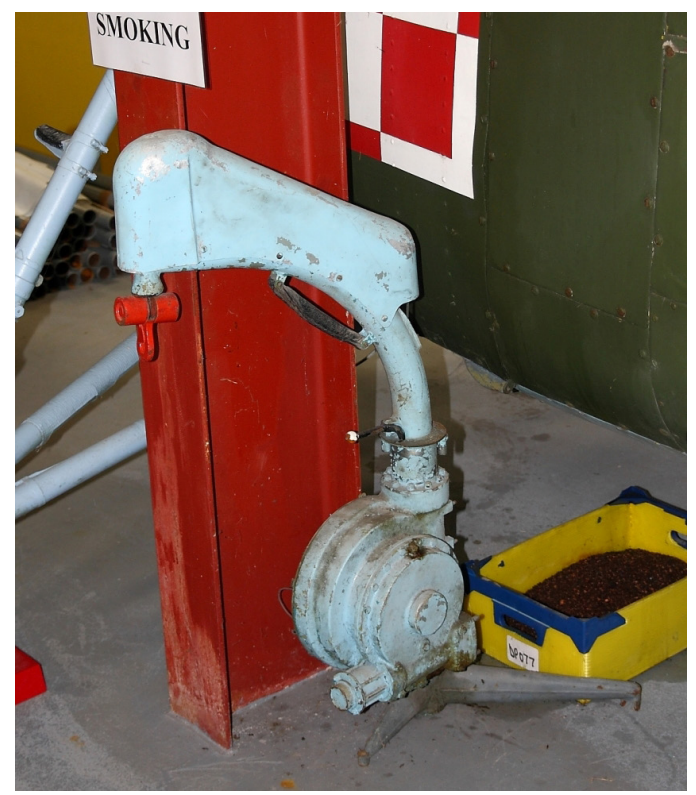

Fig. 9. Most likely the only surviving winch installed on the SM-2, currently located at the Helicopter Museum in Weston-super-Mare, Great Britain, image - Miłosz Rusiecki.
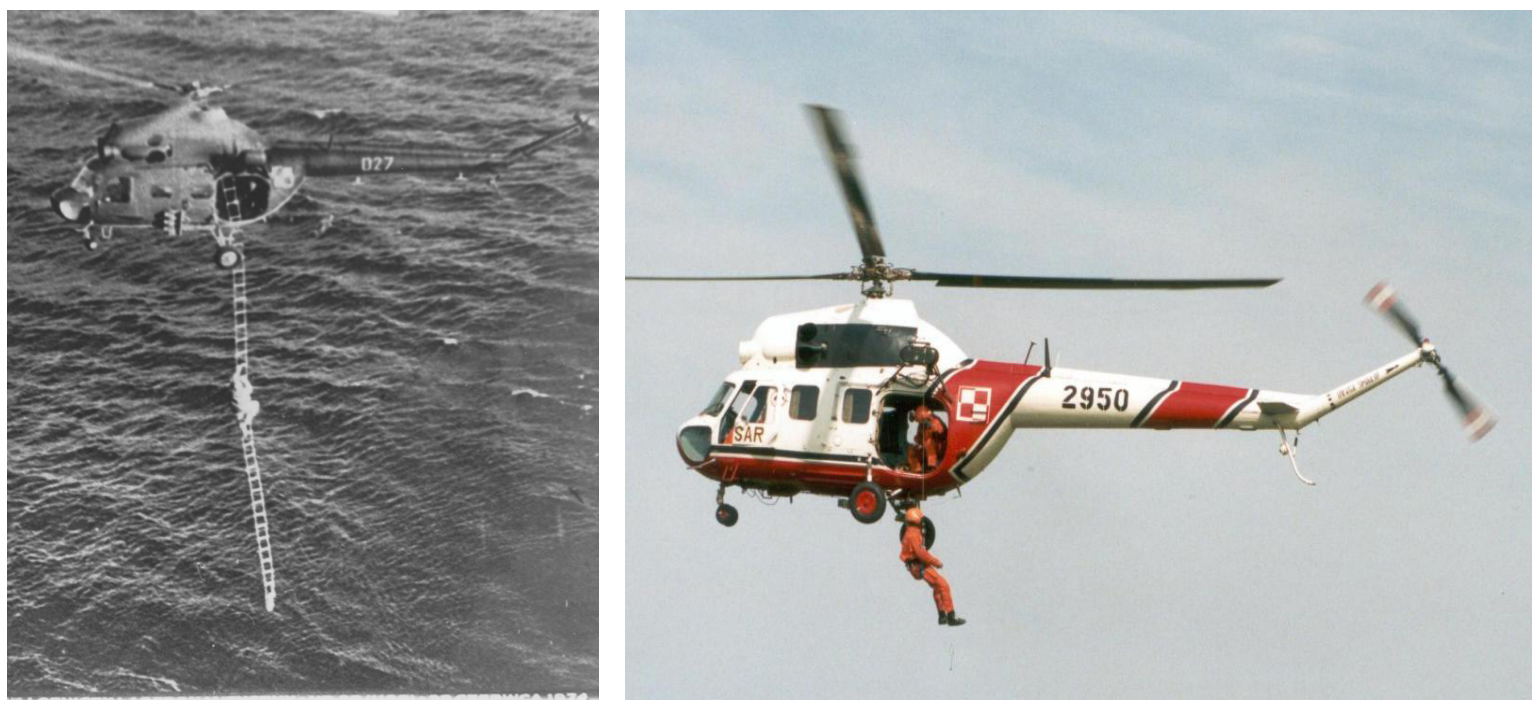

Fig. 10. Very good technical skills were required to climb aboard the helicopter using the rope ladder (left). It was impossible to use this method to lift an injured or an unconscious person. The image from the early stages of the helicopters' service life shows them sporting the original olive green liveries, the same as used on other military helicopters. Hydraulic, and then electric winches installed on the Mi-2RM made it possible to lower and hoist two people simultaneously - e.g. a rescuer and a victim (right). Images: WAF and Miłosz Rusiecki

The first real life mission was conducted on 12 August 1970. A crew stationed at the 18 E£ in Gdynia, commanded by flight lieutenant Józef Gomółka found a sailboat that capsized in the Puck Bay and lifted one of the sailors aboard. The operational debut of the Darłowo base took place on 
29 October 1970, when pilots and rescuers from the 28 ER commanded by captain Romuald Kowiel rescued the crew of the Danish "West Star" vessel,

In total, over 20 rescue missions conducted with the use of Mi-2RM helicopters have been recorded in the chronicles of the Naval Aviation between 1970 and 1992 (23 years). Seemingly, the number is not impressive, as the Mi-2RMs were taking part, on average, in one rescue mission per year. But they have saved the lives of many people (in many cases, more than one person per mission). The new helicopters made it also possible to conduct rescue missions as much as $80 \mathrm{~km}$ off the shore (in one case a flight of approximately $100 \mathrm{~km}$ into the sea was performed), while the SMs could only reach distances that guaranteed having the coastline in sight. It is also worth remembering that after 1984 some of the rescue tasks were taken over by the heavy, long-range Mi-14PS helicopters (currently replaced by Mi-14PŁR). Since 1992, the more technologically advanced W-3RM / ARM "Anakonda” are in use as well, with Mi-2RM increasingly relied upon for training and support roles. It should be stressed as well that an official agreement was concluded in December 1988 with the Polish Offshore Rescue Company (PRO, establishing the rules of cooperation while conducting search and rescue missions.
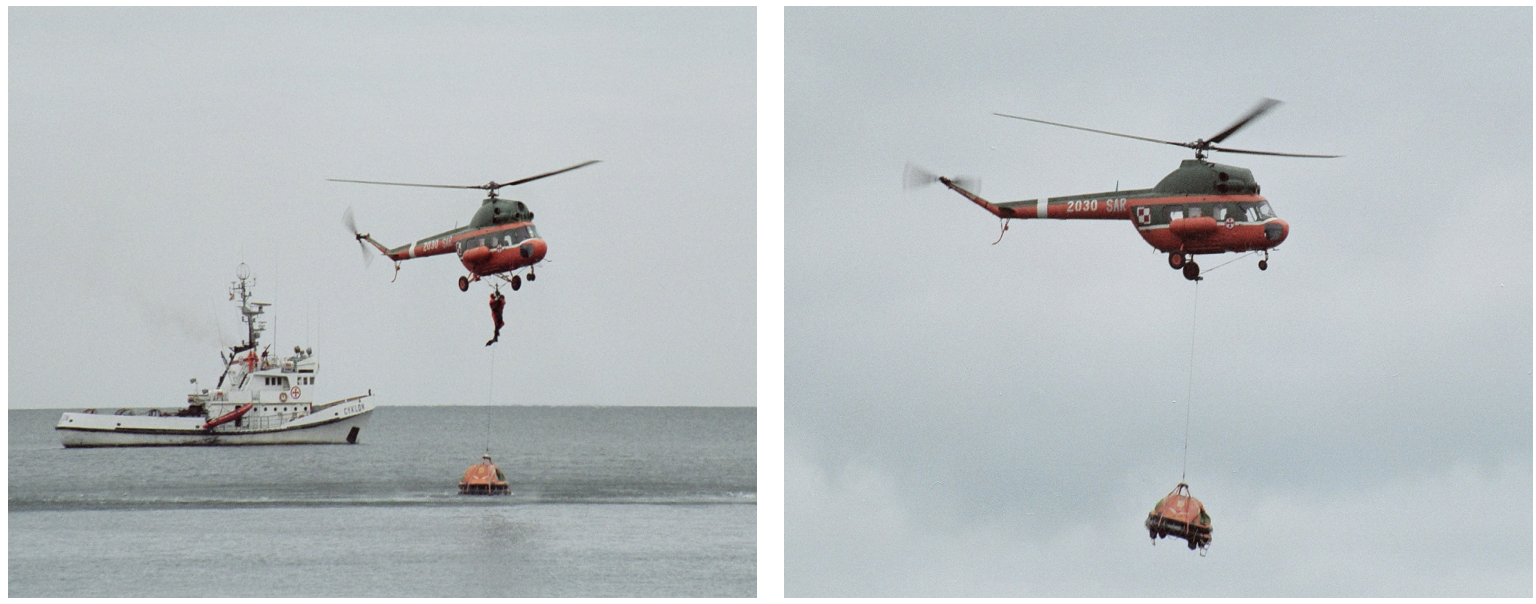

Fig. 11. A display rescue mission stages during the Sea Days 1991. Left - hoisting a victim from a rescue raft, right - transporting the raft attached to an outboard store. Should a need arise, a raft with accident victims could also be towed along the surface of the sea. Images: Miłosz Rusiecki

The Mi-2RM was also the first Polish helicopter to have landed aboard of seagoing vessels. It is most likely that the first event of this type took place during a presentation for a Libyan committee acceptance of the first of the $773 \mathrm{KL} / 3$ landing ships built for Libya in the Naval Shipyard. On 12 November 1978, Mi-2RM serial number 2706 landed on the ship's helipad. 8 vessels of this type have been built in total ( 4 for Poland and 4 for Libya). It remains unclear, however, whether such tests were performed while commissioning each one of them.

On 9 and 10 May 1988, in turn, Mi-2RM and Mi-14PS participating in the "Petrobaltic 88" exercise landed on an oil rig. 

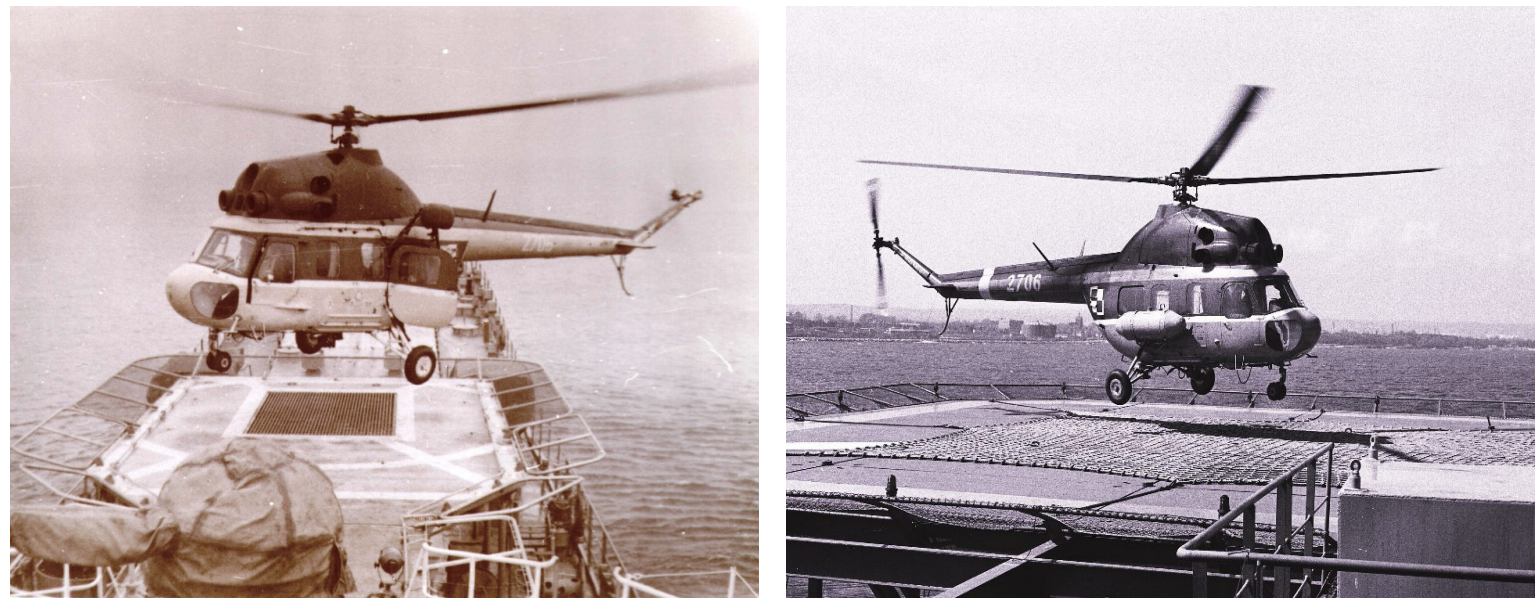

Fig. 12. Left - A Mi-2RM landing on the helipad of an assault ship built for Libya, 12 November 1978. Image - Jarosław Ciślak’s collection, Right - Mi-2 RM landing on a Petrobaltic rig during an exercise in May 1988. Image - Miłosz Rusiecki's collection

After the mid-1990s, Mi-RM were not used for performing rescue mission that often. Instead, they were relied upon to train the crews of other types of helicopters. Finally, they were decommissioned at the end of the first decade of the new century, with the last machine removed from service in March 2010. Several units have been converted into the multi-purpose variant, two have been adapted to serve as carriers of the WDZ-80 smokescreen generating system.

The latter version, which has finally given rise to one of the most peculiar versions of the rotorcraft, namely the Mi-2Ch "Hekla", it was the Navy that served as a driving force behind wide-scale tests involving masking vessels and port facilities. Representatives of the Navy participated in the work conducted at the Institute of Aviation since its very beginning in 1980. Lieutenant Commander Lucjan Zasiślak from the 28 Navy Squadron in Gdynia was one of the first military pilots to have conducted operational tests of the machine. In 1981 a wide-scale test program was conducted assessing the effectiveness of hiding, moving and stationary vessels, shore landing forces and various facilities in the port. Different ingredients of the smoke-generation mixture were tested, as were the best methods for deploying the smokescreen under different weather conditions. Simultaneous use of the smokescreen and a cloud of dipoles was tested as well, considered to be a means of shielding the vessel not only against visual observation, but also protecting it from detection by means of radar. After the tests, the Naval Aviation was equipped with the WDZ-80 smoke generators. As mentioned above, the decision to buy brand new Mi-2Ch helicopters was not made. Instead, two units of the Mi-2RM variant were adapted and were capable of operating the smoke generators. The deployment of smokescreens was demonstrated later at numerous occasions as part of military exercise sessions.

Mi-2 helicopters were used by the Naval Aviation to perform other tasks as well, with their character being similar to those performed by the machines operated by WLOP (Air and Air Defense Force) and LWL (Land Forces' Aviation). These included: transporting people and goods, performing communication flights, conducting aerial reconnaissance, detecting contamination, etc. On one occasion a Mi-2 was used in a lifting operation: on 27 December 1971, a crew from 18. ELŁ, led by flight captain Józef Gomółka erected a mast for the antenna of Polish Television’s Channel 2 in Gdynia-Redłowo. 

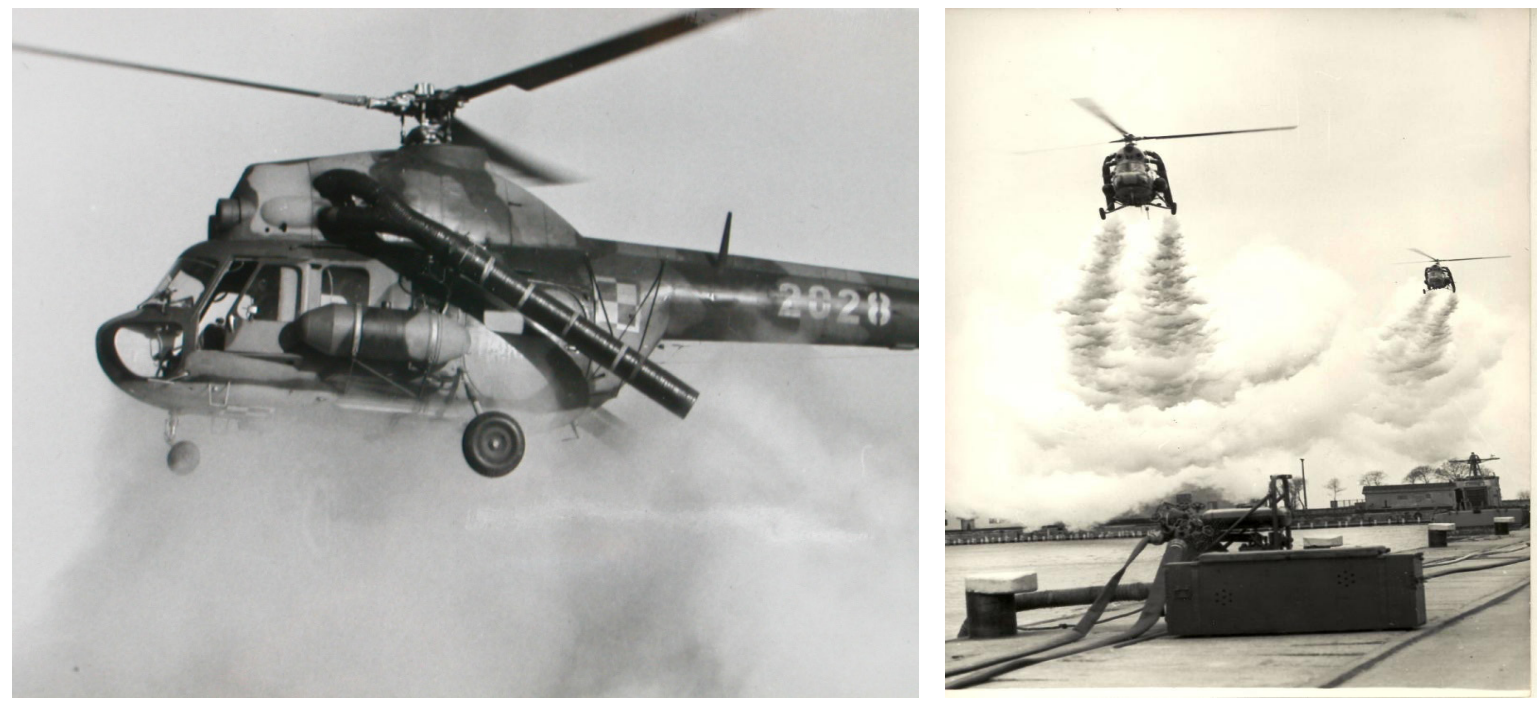

Fig. 13. Left - a rebuilt Mi-2RM with the WDZ-80 smokescreen generator, hovering during a display flight. Image: Institute of Aviation, Right - a pair of Mi-2RMs with smoke generators during a smoke screen laying exercise, port of Hel, the end of the 1980s. Image: Ireneusz Sobieszczuk

A single unit of the Mi-2D (command post version) with encrypted communications equipment was in use as well, and was relied upon to communicate with different military units. This particular machine, serial number 5245, was transformed, at the end of the 1990s, into a multipurpose version and remains in service until this day, as the last of the originally delivered sea variants of the Mi-2. The Naval Aviation is also using three other units taken over from other formations. These are relied upon primarily for crew training, also with the use of nigh vision goggles.
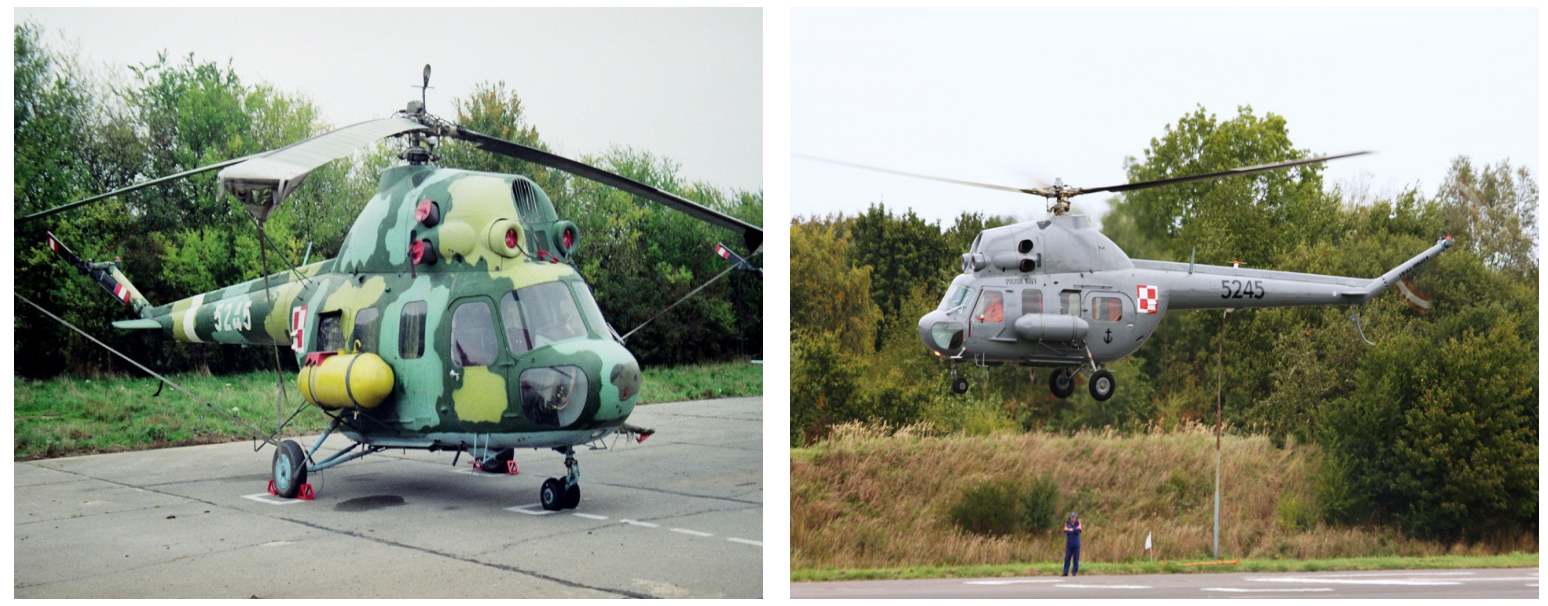

Fig. 14. The machine with the serial number 5245 is the longest-serving helicopter used by the Naval Aviation (although the force has not been its owner since day one of its service life). Left - the same machine, still as the Mi-2D (command post) variant, in the 1st half of the 1990s, right - presently, as a multi-purpose helicopter used NVG training. Images: Miłosz Rusiecki 
The crews of helicopters serving in the Land Forces' Aviation, also those flying Mi-2s, have been conducting flights over the sea, at least once per year, for 40 years now. The Central Air Force Range near Ustka are also used for live ammunition firing to water and air targets.

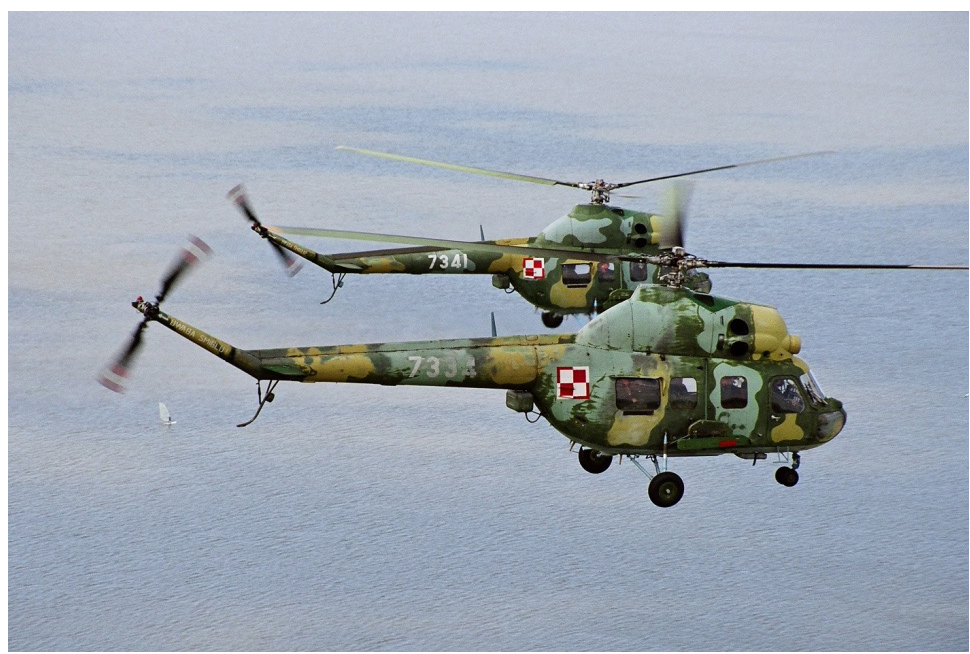

Fig. 15. A pair of Mi-2s from the 56 Combat Helicopters Regiment during in a training flight over the sea. Image: Miłosz Rusiecki

\section{CIVILIAN MI-2S OVER THE SEA}

The first civilian Mi-2s performing mainly over-the-sea flights in the coastal area were two (from the total of 4) helicopters ordered by the Polish Academy of Sciences to support the Polish research program in Antarctica. The machines with the serial numbers of 535746098 (SP-SPT) and 535747 098 (SP-SPU), bore $\alpha$ and $\Omega$ markings, respectively. Their cockpit heating and de-icing systems were modified. Additional batteries, searchlights were installed, as was equipment enabling to navigate in polar regions. A pod with a vertically-oriented camera was mounted under the tail beam - similar to that used in the military reconnaissance variants. The helicopters were used at the Polish research stations: Henryk Arctowski base at the King George Island, and Antoni Dobrowolski based in the Bunger Bay, starting from the 1978 / 1979 season. They were usually piloted by military personnel seconded on a contract. The honor of being the first pilots goes to Naval Aviation aircrews, made up of ft. lt. Józef Litwin (28. Sqd.) and ft. lt. Wojciech Kurzyński (18. Sqd.) who performed the first flights on the King George Island on 12 December 1978.

The Marine Office in Gdynia owned the Mi-2 reg. SP-SHP (serial number 515039 017) for over 30 years. The helicopter was used to monitor Poland's coastal economic zone, to detect pollution of coastal waters, to inspect beaches, verify erosion of shorelines, inspect marine navigation aids and perform other similar tasks. It was operating primarily near the Tri-City area, and was patrolling Gdańsk and Puck Bays. It was also used as a medical helicopter, as its pilots and mechanics were employees of the Gdańsk-based Air Rescue Service. Unfortunately, this superbly equipped unit was withdrawn from service at the end of its useful life in Q1 2015, as the major overhaul proved to be economically unfeasible. 

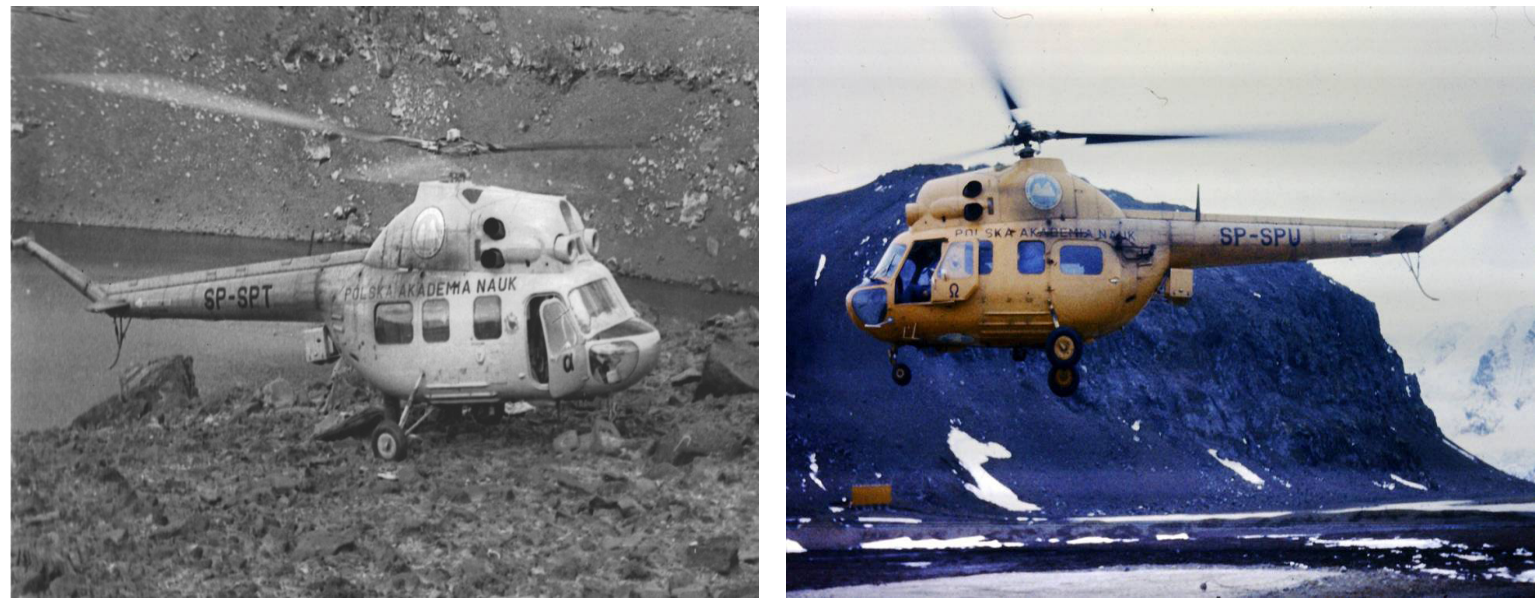

Fig. 16. Mi-2 helicopters with specialized equipment were supporting Polish Academy of Sciences staff at the Polish research bases in Antarctica since December 1978. Image to the left - collection of ft. cdr. Józef Litwin, image to the right - collection of prof. Stanisław Rakusa-Suszczewski
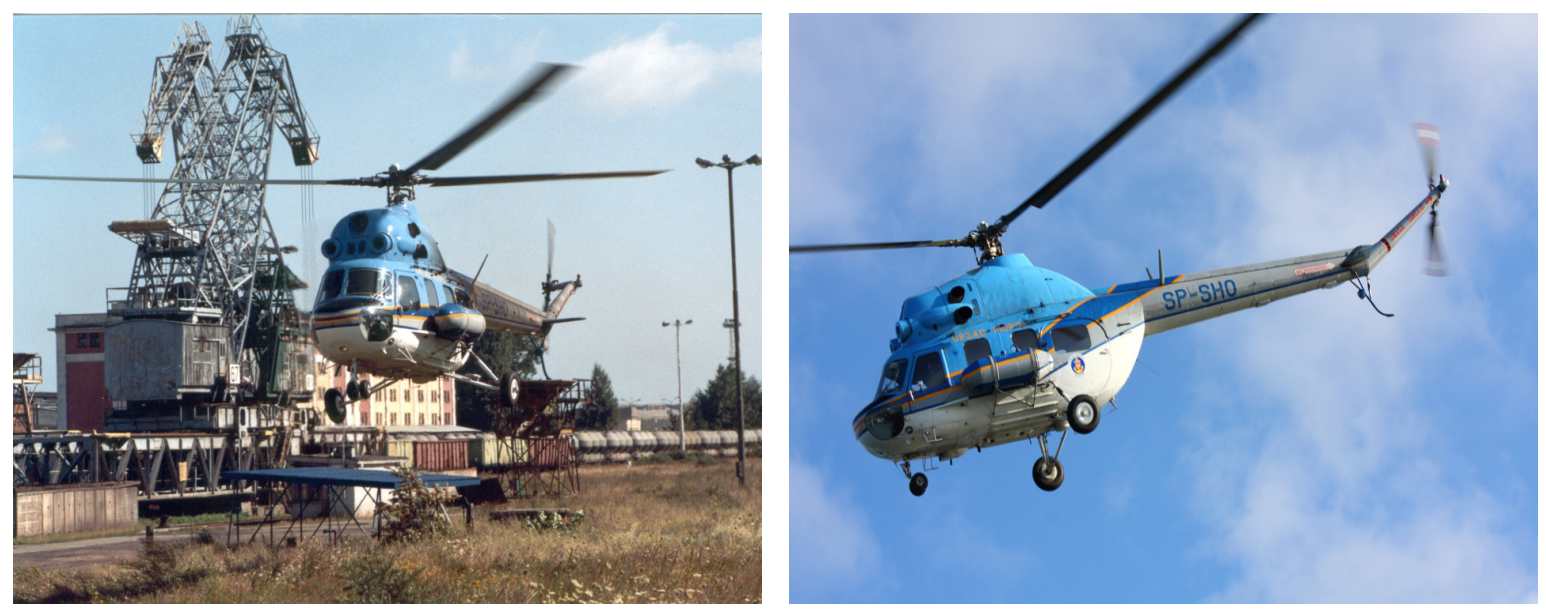

Fig. 17. Mi-2 SP-SHO used by the Marine Office in Gdynia. Left - the helicopter is landing on a makeshift helipad on the premises of the Gdynia Port. Images: Miłosz Rusiecki

\section{OVER FOREIGN SEAS}

The Soviet Union was the user of the largest number of Mi-2s operating over seas. We are not talking about armed forces here, but about civilian aviation only. Despite the fact that civilian variants of Kamov helicopters designed for operating from ships and vessels existed (Ka-18, Ka-32), the good old Mi-2 has turned out to be more popular in the polar areas of the country. Almost each of the Soviet giant, nuclear-powered icebreakers was equipped with a helicopter of this type. Icebreakers are responsible for maintaining navigational routes in the far north and in the Arctic. They also transport research expeditions, provide supplies to secluded settlements, scientific bases and stations and perform rescue missions. Over the past 20 years, they have been also serving as means of transport for thrill-seeking tourists. They are supported in that role by helicopters - in most cases by Mi-2s. The machines are used 
for assessing the condition of the ice cover along the route, for transporting people and goods, and in some cases for scenic flights with polar tourists.
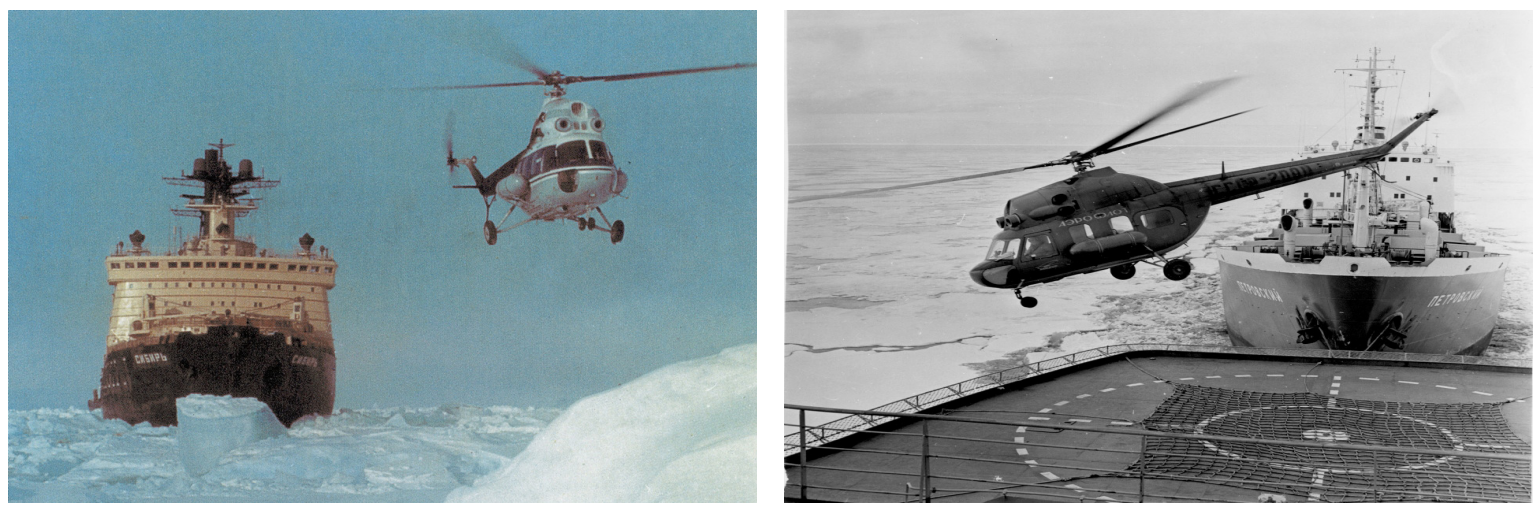

Fig. 18. Aeroflot Mi-2s cooperating with Russian deep sea icebreakers, taking off from deck helipads.

Images: left - OKB Mila, right - Photoshare.ru

It remains unconfirmed whether Mi-2s were also used as rotorcraft based on Russian whale hunting and processing vessels. Such vessels, being the largest of their class in the world, were equipped, as a standard solution, with helipads and helicopters. Scarce photographs available only show floatequipped $\mathrm{Mi}-1$ and, in sporadic cases, Kamov Ka-15 helicopters.

The service of Mi-2 helicopters in the Mexican Naval Aviation (Fuerza AeroNaval) is an interesting episode too. With the purchases of post-Soviet aircraft and helicopters gaining popularity in the mid-1990s, the government of Mexico acquired approximately a dozen Mi-2 helicopters withdrawn from service in the USSR / Russian Air Force. The majority of them were used by the Naval Aviation (16 have been identified based on photographs). No details are available concerning their use. It remains unknown whether they were really operating in off-shore scenarios, taking off from helipads on ships. The images fail to show any specialized equipment, such as rescue winches, for instance. According to various sources, only one of the Mi-2s remains in service until this day.
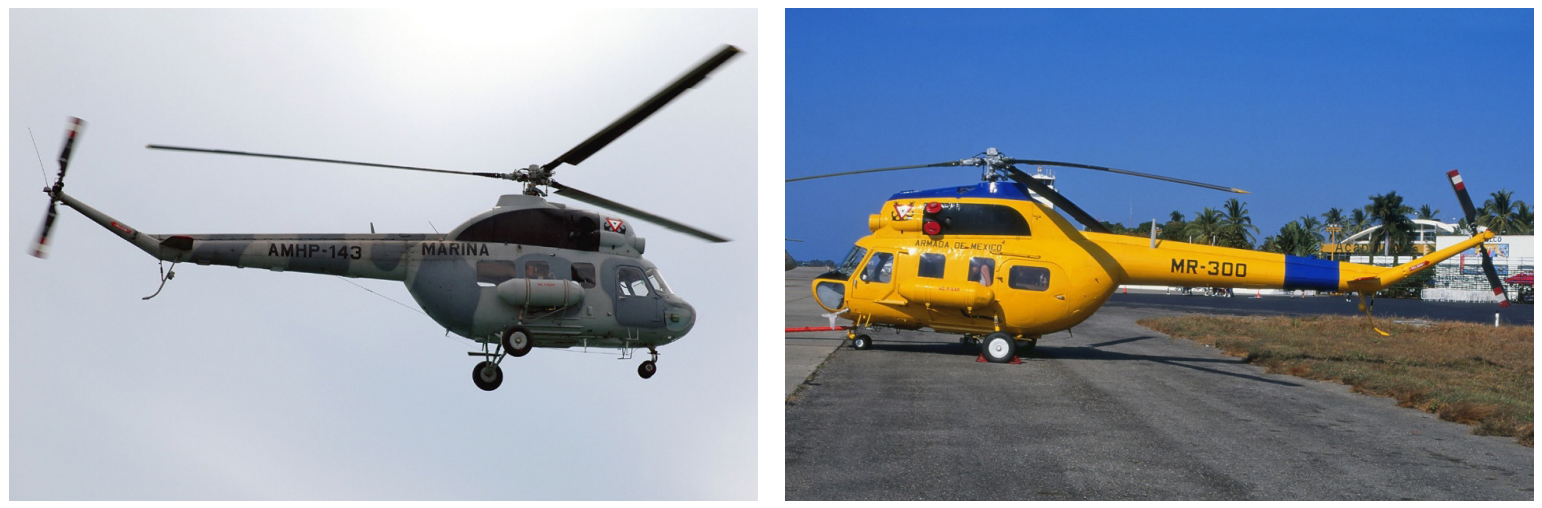

Fig. 19. Two images of Mi-2 helicopters used by the Mexican Naval Aviation in the 2000s. Images: left - Terry Nash Airliners.net, right - Thomas Girke’s collection. 


\section{CONCLUSIONS}

While entering service, Mi-2 helicopters were a modern design in their weight category. The most advanced features included dual turboshaft engines - a solution that considerably boosted the level of flight safety. Performance and limitations of the helicopter did not differ considerably from similar designs of other manufacturers, including those built in Western Europe and the USA. In comparison to earlier, piston engine-powered helicopters, the $\mathrm{Mi}-2$ was a true revolution in terms of rotorcraft design. That is why, despite not being strictly adapted to marine service, they were doing exceptionally well while performing tasks in such a harsh environment (rescue and patrolling missions, operating from vessel-mounted helipads, etc.) As the technology advance, they were gradually phased out and replace by newer designs. In some instances, they still remain in service in the 2010s.

\section{APPENDICES}

I. Comparison of payload space and powerplant dimensions of the Mi-1 (SM-1) and the Mi-2.

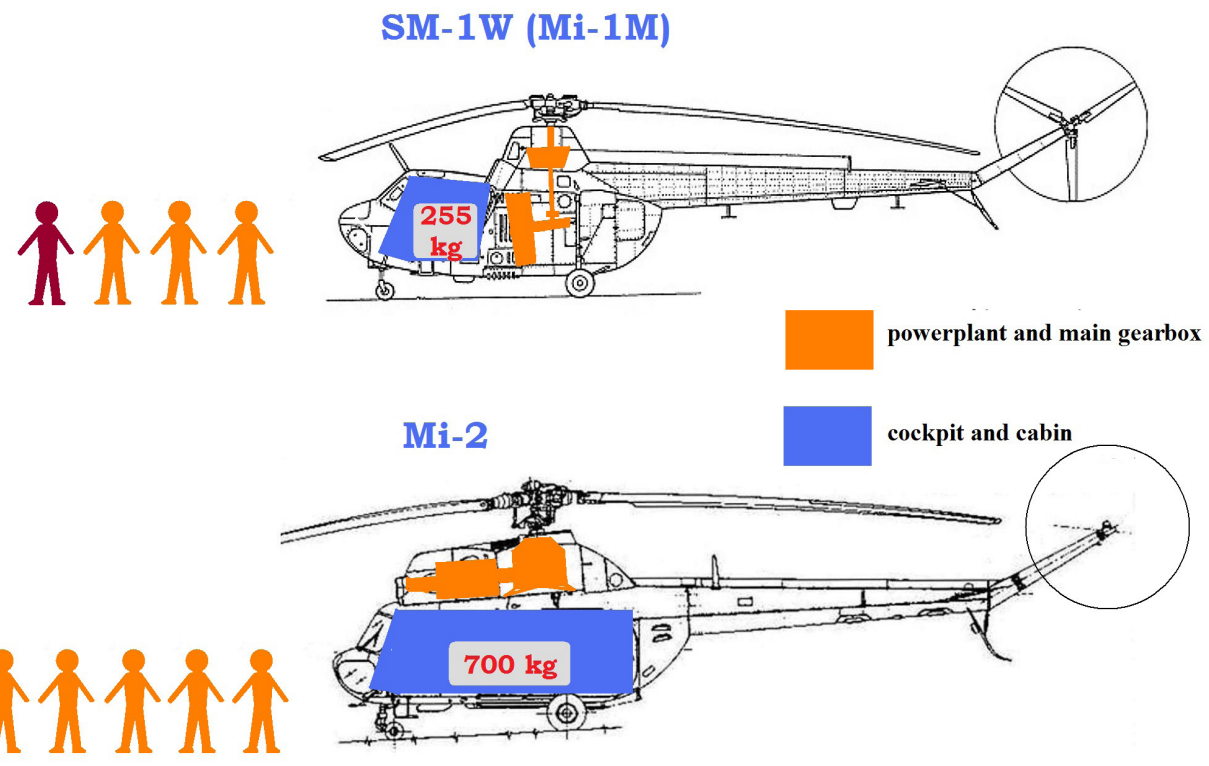

II. Comparison of performance data of the Mi-1M (SM-1W) and Mi-2 
Comparison of SM-2 and Mi-2 technical specifications:

SM-2

Powerplant:

Continuous power

Dry engine weight

\section{Dimensions:}

Fuselage length

Main rotor diameter

\section{Weights:}

- empty weight

- standard takeoff weight

- payload weight one AI-26GR / Lit-3

radial piston engine

data)

$550 \mathrm{KM}(429 \mathrm{~kW})$

$395 \mathrm{~kg}(870 \mathrm{lb})$

$12,09 \mathrm{~m}$ (39 ft 8 in)

$14,35 \mathrm{~m}(47 \mathrm{ft} 1 \mathrm{in})$

$1,700 \mathrm{~kg}(3,747 \mathrm{lb})$

$2,140 \mathrm{~kg}(4,717 \mathrm{lb})$

$255 \mathrm{~kg}(562 \mathrm{lb})$
Mi-2

two GTD-350 turboshaft

engines (single engine

$400 \mathrm{KM}(298 \mathrm{~kW})$ each

$193,3 \mathrm{~kg}(426 \mathrm{lb})$

$11,40 \mathrm{~m}(37 \mathrm{ft} \mathrm{4,8}$ in $)$

$14,56 \mathrm{~m}$ (47 ft $67 / 8 \mathrm{in})$

$2,372 \mathrm{~kg}(5,218 \mathrm{lb})$

$3,550 \mathrm{~kg}(7,826 \mathrm{lb})$

$700 \mathrm{~kg}(1,543 \mathrm{lb})$

\section{Performances:}

$\begin{array}{ll}\text { Maximum speed } & 185 \mathrm{~km} / \mathrm{h}(100 \mathrm{knots}) \\ \text { Cruising speed } & 145 \mathrm{~km} / \mathrm{h}(78 \mathrm{knots}) \\ \text { Climb rate } & 5 \mathrm{~m} / \mathrm{s} \\ \text { Maximum service ceiling } & 3,500 \mathrm{~m}(11,482 \mathrm{ft}) \\ \text { Maximum range } & 430 \mathrm{~km}(232 \mathrm{nmi})\end{array}$

Maximum speed

Climb rate

$3,500 \mathrm{~m}(11,482 \mathrm{ft})$
$430 \mathrm{~km}(232 \mathrm{nmi})$

\footnotetext{
(single control variant, $\mathrm{T} / \mathrm{O}$ weight $3550 \mathrm{~kg} / 5,218 \mathrm{lb}$, standard atmosphere, wind $0 \mathrm{~m} / \mathrm{s}$ )

$210 \mathrm{~km} / \mathrm{h}$ (113 knots)

$190 \mathrm{~km} / \mathrm{h}$ (102 knots)

$4,5 \mathrm{~m} / \mathrm{s}$

$4,000 \mathrm{~m}(13123 \mathrm{ft})$

$400 \mathrm{~km}(216 \mathrm{nmi})$

(no auxiliary tanks, four

passengers, $5 \%$ fuel

reserve)
}

\section{List of abbreviations}

EE

(Eskadra Łącznikowa) Liaison Squadron

ER

(Eskadra Ratownicza) Search and Rescue Squadron

ELE

(Eskadra Lotnictwa Łącznikowego) Liaison Aviation Squadron

ITWL

(Instytut Techniczny Wojsk Lotniczych) Air Forces Institute of Technology

LMW

(Lotnictwo Marynarki Wojennej) Naval Aviation

LWL

(Lotnictwo Wojsk Lądowych) Army Aviation

MW

(Marynarka Wojenna) Navy

NVG

Night Vission Goggles

$\mathrm{OKB}$

(Russian: Opytno-Konstruktorskoye Byuro) Experimental-Engineering Bureau

PAN

(Polska Akademia Nauk) Polish Academy of Sciences

WAF

(Wojskowa Agencja Fotograficzna) Military Photographic Agency

WLOP

(Wojska Lotnicze i Obrony Powietrznej) Air and Air Defence Forces (currently Air Forces)

WSK PZL (Wytwórnia Sprzętu Komunikacyjnego Państwowe Zakłady Lotnicze) Transport Equipment Plant National Aviation Factory 


\section{IBLIOGRAPHY}

\section{Books}

[1] R. Witkowski 1986, "Rotorcraft in Poland" ("Wiropłaty w Polsce"), Wydawnictwa Komunikacji i Łączności, Warsaw.

[2] M. Konarski, A. Olejko 1995, "Traditions of Polish Naval Aviation - Chronology" ("Tradycje polskiego lotnictwa morskiego - kalendarium wydarzeń”), Muzeum Marynarki Wojennej, Gdynia.

[3] E. F. Rybak, J. Gruszczyński 2001, "History of PZL Świdnik Factory" ("Historia zakładów PZL-Świdnik S.A.”), Lampart, Warsaw.

[4] "Polish Medical Aviation 1955-2005" ("Polskie lotnictwo sanitarne 1955-2005”), 2005, ed. by R. Gałązowski and P. Kłosiński, Borgis Wydawnictwo Medyczne, Warsaw.

[5] J. Fojtik 2008, "Mi-2 Multirole Helicopter" - Czech language ("Viceúčelowy vrtulnik Mi-2"), Svět Křidel.

[6] V. R. Mikheyev 1998, „50 Years of Mil Moscow Helicopter Plant”, Russian language, ("MWZ im. M. L. Mila 50 liet"), Liubimaja Kniga, Moscow.

[7] V. R. Mikheyev 2007, "Mil Moscow Helicopter Plant", Polygon-Press, Moscow.

\section{Magazines}

[8] W. Burczak 1977, "Development and variants of Mi-2 helicopter" "'Rozwój i wersje śmigłowca Mi-2"), Aviation and Astronautics Technology (Technika Lotnicza i Astronautyczna), Vol. 5.

[9] J. Gruszczyński, M. Rusiecki 1996, "The Rescuers - rescue and police variants of Mi-2 helicopter" ("Ratownicy - ratownicze i policyjne wersje śmigłowca Mi-2") The Aeroplane (Aeroplan), Vol. 4.

[10] C. Piotrowski 1996, "Mi-2 in Polish military aviation" ("Mi-2 w polskim lotnictwie wojskowym") The Aeroplane (Aeroplan), Vol. 5.

[11] Je. Gordon, D. Komissarow 2000, "Mi-2 light multirole helicopter", Russian language, ("Lyegkiy mnogotselevoy vertaliot Mi-2"), Aviatsya / Aviation Magazine, Vol. 7.

[12] D. Komissarow, A. Kotłobowskij, M. Rusiecki, A. Chaustow 2004, "Helicopter with double citizenship", Russian language, ("Vertaliot s dvoynom grazhdanstvom"), Aviation and Times" (Aviatsya y Vremya).

[13] A. Gołąbek, A. Wrona 2016, "Mi-2 helicopters in Polish military aviation - part 1 and 2" (“Śmigłowce Mi-2 w polskim lotnictwie wojskowym” cz. 1 i 2), Lotnictwo - Aviation International, Vol 11-12.

[14] K. Budniak 2016, "SM-2 helicopter" ("Śmigłowiec SM-2"), The Aeroplane (Aeroplan), Vol. 5/6.

[15] M. Rusiecki 2017, "Mi-2 - helicopter for every task, civil versions" "Mi-2 - śmigłowiec do wszystkiego, wersje cywilne" Lotnictwo - Aviation International, Vol. 4.

[16] M. Rusiecki 2017, "Mi-2 - helicopter for every task, military versions" ("Mi-2 - śmigłowiec do wszystkiego, wersje wojskowe"), Lotnictwo - Aviation International, Vol. 5.

[17] S. Bartosik, M. Rusiecki, R. Senkowski 2017, "The flying smokers - the beginning" ("Powietrzni zadymiacze - początki”), Aeromax.PL, Vol. 4.

\section{Online publications}

[18] Information from the official website of the Naval Aviation Brigade http://blmw.wp.mil.pl/pl (viewed on November 17, 2017).

[19] Website http://www.helicopter-database.de (viewed on November 22, 2017). 


\section{ŚMIGŁOWCE MI-2 W DZIAŁANIACH NA MORZU}

\section{Streszczenie}

W artykule omówiono zastosowanie śmigłowców Mi-2 w wojskowych i cywilnych działaniach na morzu. Jakkolwiek wielozadaniowe Mi-2 nie były konstruowane z myślą o działaniach w trudnym środowisku morskim, to jednak w II połowie lat 60. i w kolejnej dekadzie stały się standardowym typem wykonującym zadania nad morzem. Nowoczesny napęd turbowałowy, korzystny stosunek mocy silników do masy oraz układ dwusilnikowy pozwalały na bezpieczne loty nad morzem w znacznej odległości od lądu. Dzięki opracowanej w zakładach WSK PZL Świdnik specjalistycznej wersji Mi-2RM lotnictwo Marynarki Wojennej mogło w I połowie lat 70. stworzyć unikalny system lotniczego ratownictwa morskiego. Ostatni ratowniczy Mi-2RM został wycofany ze służby dopiero w 2010 r., choć był wówczas wykorzystywany już tylko do treningu załóg. Ponadto w Marynarce Wojennej stosowano wersję Mi-2Ch do stawiania zasłon dymnych maskujących okręty i obiekty portowe. Wersje ogólnoużytkowe wykorzystywano do przewozów ludzi i ładunków, patrolowania, rozpoznania skażeń itp.

Z kolei w służbie cywilnej do historii przeszło użycie specjalnie wyposażonych Mi-2 do wsparcia badań obszarów antarktycznych prowadzonych przez naukowców na dwóch stacjach Polskiej Akademii Nauk. Także Urząd Morski w Gdyni przez blisko 30 lat do 2015 r. dysponował własnym śmigłowcem Mi-2 do patrolowania rejonu zatok Gdańskiej i Puckiej oraz wód Półwyspu Helskiego, a w szczególności do wykrywania skażeń morskich wód przybrzeżnych.

W Związku Radzieckim cywilne Mi-2 do dziś stanowią wyposażenie wielkich lodołamaczy dalekomorskich, które pływają po wodach Arktyki włącznie z rejonem bieguna północnego, zabezpieczając bezpieczeństwo żeglugi, przewożąc wyprawy naukowe oraz grupy ekstremalnych turystów. Z kolei kilkanaście Mi-2 odkupionych od Rosji w połowie lat 90. ub. wieku używało Lotnictwo Marynarki Wojennej Meksyku, jednak brak jest bliższych informacji o szczegółach tych działań.

Słowa kluczowe: śmigłowce, eksploatacja na morzu, wersje śmigłowca Mi-2, wojskowe i cywilne zastosowania śmigłowca Mi-2.

\section{ACKNOWLEDGMENTS}

The article could not be completed without the help of friendly pilots, technicians, aviation historians and photographers who have shared their materials, information and images with me. I hereby take the opportunity to thank them for the support they have shown. They include, in particular:

Sławomir Bartosik, Paweł Bondaryk, Karol Budniak, Jarosław Ciślak, Tadeusz Drybczewski, Remigiusz Gadacz, Thomas Girke, Andrzej Glass, Jefim Gordon, Jerzy Gruszczyński, Wacław Hołyś, Mariusz Kalinowski, Mariusz Konarski, Wojciech Kurzyński, Józef Litwin, Kazimierz Pogorzelski, Zbigniew Rakoczy, Robert Senkowski, Marcin Sieradzki, Zbigniew Smolarek, Roman Tański, Stanisław Wielgus, Ryszard Witkowski, Andrzej Wrona, as well as the flying and maintenance personnel Naval Aviation of and ZLS / LPR Gdańsk 